This item was submitted to Loughborough's Research Repository by the author.

Items in Figshare are protected by copyright, with all rights reserved, unless otherwise indicated.

\title{
Is employee narcissism always toxic? - The role of narcissistic admiration, rivalry, and leaders' implicit followership theories for employee voice
}

\section{PLEASE CITE THE PUBLISHED VERSION}

https://doi.org/10.1080/1359432X.2019.1575365

\section{PUBLISHER}

(C) Taylor \& Francis (Routledge)

\section{VERSION}

AM (Accepted Manuscript)

\section{PUBLISHER STATEMENT}

This is an Accepted Manuscript of an article published by Taylor \& Francis in European Journal of Work and Organizational Psychology on 22 February 2019, available online:

http://www.tandfonline.com/10.1080/1359432X.2019.1575365.

\section{LICENCE}

CC BY-NC-ND 4.0

\section{REPOSITORY RECORD}

Helfrich, Hannah, and Erik Dietl. 2019. "Is Employee Narcissism Always Toxic? - the Role of Narcissistic Admiration, Rivalry, and Leaders' Implicit Followership Theories for Employee Voice". Loughborough University. https://hdl.handle.net/2134/36698. 
Is employee narcissism always toxic? - The role of narcissistic admiration, rivalry, and leaders' implicit followership theories for employee voice

Hannah Helfrich

University of Hohenheim, Stuttgart, Germany

Erik Dietl

Loughborough University, Loughborough, United Kingdom

Manuscript accepted for publication in

European Journal of Work and Organizational Psychology - January 2019

The manuscript may not exactly replicate the final version published in the journal. It is not the copy of record. The final article will be available, upon publication, via its DOI.

\section{Acknowledgements}

This research was partly funded by Gips-Schüle Stiftung (www.gips-schuele-stiftung.de). We would like to express our gratitude to Frank Walter for his excellent comments on an earlier version of this article, and to Konrad Senf for proofreading an earlier version of this article. We also thank Julia Guba, Lilija Guk, Philipp Hassel, Nadine Haug, Madeleine Horka, Ariane Metz, Melanie Nguyen, Evgenia Petritziki, Catharina Schmidt, Anja Tomschitz, Charlotte Zimmerle, and Sabina Zimmermann for their help in collecting data. Correspondence concerning this article should be directed to: Hannah Helfrich, Business and Organizational Psychology, University of Hohenheim, Wollgrasweg 49, 70599 Stuttgart, Germany, E-mail: hannah.helfrich@online.de; and: Erik Dietl, School of Business and Economics, Loughborough University, Loughborough, Leicestershire, LE11 3TU, United Kingdom, E-mail: e.dietl@lboro.ac.uk 


\title{
Is employee narcissism always toxic? -
}

The role of narcissistic admiration, rivalry, and leaders' implicit followership theories for employee voice

\begin{abstract}
Organizational researchers are increasingly interested in investigating the influence of narcissism on the workplace. Drawing on self-determination theory and recent research that distinguishes two dimensions of narcissism and their different underlying motivational dynamics, we hypothesised that employee empowerment, and in turn voice, are differentially influenced by the two narcissism facets admiration and rivalry. In particular, we expected that employees' narcissistic admiration is positively related to voice via empowerment, whereas rivalry is negatively related to voice via empowerment. Moreover, we investigated leaders' implicit followership theories (IFTs) as moderator of the relationships between narcissistic rivalry and narcissistic admiration with empowerment. We argue that a leader's positive IFTs buffer the negative effect of narcissistic rivalry and foster the positive effect of narcissistic admiration on empowerment, and in turn voice (i.e., first-stage moderated mediations). We found support for most of our predictions in a multi-wave field study using data from 268 leader-employee dyads. Theoretical and practical implications are explored.
\end{abstract}


Organizational researchers have become increasingly interested in the effects of narcissism in the workplace (e.g., Grivalja \& Harms, 2014; Grijalva, Harms, Newman, Gaddis, \& Fraley, 2015; Judge, LePine, \& Rich, 2006). By definition, narcissism consists of inflated self-views and delusions of grandeur that create a longing for self-promotion and attention-seeking behaviours (O'Boyle, Forsyth, Banks, \& McDaniel, 2012). Many studies investigated leader narcissism (Chatterjee \& Hambrick, 2007; Hoffman et al., 2013), but there is only little research on non-managerial employee narcissism (Campbell, Hoffman, Campbell, \& Marchisio, 2011). Studies that investigated narcissism found it to be associated with approach-avoidance and intrinsic motivation, counterproductive work behaviour, job performance and job satisfaction (Foster \& Trimm, 2008; Judge et al., 2006; Morf, Weir, \& Davidov, 2000; Penney \& Spector, 2002; Soyer, Rovenpor, \& Kopelman, 1999).

Several researchers considered narcissism as a global construct (Judge et al., 2006; Mathieu, 2013; Penney \& Spector, 2002; Reina, Zhang, \& Peterson, 2014; Wisse, Barelds, \& Rietzschel, 2015), and this research has produced contradictory findings (Grijalva et al., 2015; Jonason, Wee, \& Li, 2015; Judge et al., 2006; Mathieu, 2013; Soyer et al., 1999). These mixed findings aroused interest in the question whether narcissism is negative or positive for organizational functioning (Campbell et al., 2011). The reason for these contradictory findings might be traced back to the fact that facets of narcissism have been neglected. Therefore, recent models of narcissism consider different facets and different underlying motivational and behavioural processes (Aghaz, Atashgah, \& Zoghipour, 2014; Back et al., 2013; Lange, Crusius, \& Hagemeyer, 2016; Weiser, 2015). We also consider facets of narcissism and investigate employee narcissism under a motivational lens. We draw on the model by Back et al. (2013) that differentiates between two facets of narcissism admiration and rivalry - and considers their underlying motivational dynamics. These two facets may explain why narcissism appears to be related to opposite processes and distinct 
underlying motivational dynamics leading to distinct consequences: On the one hand, narcissists are highly motivated to approach desirable outcomes (Foster \& Trimm, 2008), and their self-assuredness can equip them with enormous energy, which often fascinates others. On the other hand, narcissists' motivation to protect their self from losing its grandiosity, which often triggers a devaluation of others, may hold back their progress and quench people (Back et al., 2013).

We draw on self-determination theory (SDT; Ryan \& Deci, 2000) and the Narcissistic Admiration and Rivalry Concept (NARC; Back et al., 2013) to investigate how narcissistic admiration and rivalry differentially impact employee intrinsic motivation (i.e., empowerment) and self-determined behaviour (i.e., voice). The SDT, a theory of work motivation, highlights the importance of autonomous motivation and its underlying regulatory processes and accompanying experiences (Gagné \& Deci, 2005). We expect that intrinsic motivation, an example of autonomous motivation (Gagné \& Deci, 2005), will be differentially affected by narcissistic admiration and rivalry, because their underlying motivational processes are distinct (Back et al., 2013). Consequently, we examine the influence of the two facets on employee empowerment, which is an important motivational construct in organizational psychology (Conger \& Kanungo, 1988; Liden, Wayne, \& Sparrowe, 2000; Spreitzer, 1995) reflecting intrinsic motivation (Thomas \& Velthouse, 1990). Empowerment has been defined as the motivational concept of self-efficacy and includes several components such as competence and self-determination (Conger \& Kanungo, 1988; Spreitzer, 1995). Moreover, we investigate how empowerment affects a selfdetermined behaviour that is gaining increased importance in the work context - employee voice. Voice is a form of extra-role behaviour, which is positive and discretionary, not specified as in-role descriptions and not rewarded by formal reward systems (Van Dyne \& LePine, 1998). The pressure for greater efficiency and performance due to globalization has 
reinforced the research interest in employee performance, especially extra-role behaviour such as voice. Moreover, the concept of work has changed due to dynamic environments. Today, not all tasks that an employee has to perform are specified in the job description and furthermore, it is simply not possible to specify all desired employee behaviours. Therefore, employees' extra-role behaviour is especially valued by leaders (Van Dyne \& LePine, 1998). In addition, extra-role behaviour such as voice cannot be controlled by information systems and control mechanisms in comparison to in-role behaviour that can be monitored via behaviour control (Piccoli, Powell, \& Ives, 2004). Due to these reasons, it is necessary that employees perform voice behaviour volitionally. This underlines the self-determined character of voice behaviour.

SDT argues that all individuals have "natural, innate and constructive tendencies to develop an ever more and elaborated and unified sense of the self' (Deci \& Ryan, 2002; p. 5). This tendency describes an intrinsic need for self-determination which is linked to empowerment (Spreitzer, 1995). Therefore, empowering employees is a useful strategy to support their self-determination needs (Nassar, 2017). However, there are social-contextual factors that either support or hinder this tendency (Deci \& Ryan, 2002) and thus empowerment. Therefore, we examine the leader as an important social-contextual factor. More specifically, we consider a leader's implicit followership theories (IFTs) that describe a leader's assumptions about the characteristics of employees (Sy, 2010). We investigate implicit theories because they directly affect leaders - their perceptions, evaluations, and actions - thereby representing one of the most powerful contextual factors influencing workplace processes (Engle \& Lord, 1997; Sy, 2010). We argue that a leader's IFTs can support or hinder an employee's empowerment depending on if the IFTs are positive.

Taken together, we investigate the influence of narcissistic admiration and rivalry on empowerment and voice and integrate leaders' IFTs as a social-contextual factor. We test our 
predictions in a three-wave study of 268 leader-employee dyads. Our research makes several contributions. We consider narcissism, empowerment, voice and leaders' IFTs in light of a motivational self-determination framework. This helps to better understand underlying mechanisms and extends past research on the motivational aspects of narcissism (Foster \& Trimm, 2008). We also extend the NARC model, which suggests that situational cues play a role in the expression of narcissism (Back et al., 2013) by identifying a leaders' IFTs as a moderator. Moreover, we show that narcissistic admiration and rivalry differently predict employees' intrinsic motivation (i.e., empowerment) and subsequently their self-determined behaviour - employee voice. This demonstrates that it is important to differentiate between facets of narcissism and implicates that narcissism does not have either positive or negative effects, but both. We also underline the necessity to examine leaders and employees jointly to shed light on the leader-follower interaction. The results show that the leader can play a crucial role in the process of empowering employees.

\section{Theory}

\section{Narcissism in organizational research}

Clinical psychologists first identified narcissism as a personality disorder (Kernberg, 1975; Pincus \& Lukowitsky, 2010). According to the Diagnostic and Statistical Manual of Mental Disorders (DSM-IV; American Psychiatric Association, 1994), the main features of this disorder are "a pervasive pattern of grandiosity (in fantasy or behavior), need for admiration, and lack of empathy" (p. 661). Individuals who suffer from this narcissistic personality disorder tend to exaggerate their accomplishments and have an imposing sense of self-importance (American Psychiatric Association, 1994). While the clinical diagnosis is dichotomous, personality psychologists view milder forms of narcissism as a continuous personality trait (Carpenter, 2012; Lee \& Ashton, 2005; Paulhus \& Williams, 2002). This non-clinical type of narcissism includes a complex of personality traits and processes comprising a grandiose yet fragile sense of self, concern for success and demands for 
admiration (Ames, Rose, \& Anderson, 2006). In this article, we refer to narcissism as a continuous personality trait in the nonclinical population.

\section{Narcissistic admiration and narcissistic rivalry}

Back et al. (2013) introduced the Narcissistic Admiration and Rivalry Concept (NARC) that differentiates between two facets: narcissistic admiration (assertive selfenhancement) and narcissistic rivalry (antagonistic self-protection), thereby considering underlying motivational processes. The two facets are related but far from interchangeable. The NARC suggests that persons differ not only in their general tendency to use selfregulation processes with the aim of maintaining a grandiose self (and thus in their expression of narcissism) but also in the strength with which they activate self-enhancement and selfprotection to do so (Back et al., 2013; Wurst et al., 2017). Narcissistic admiration consists of three intertwined domains: striving for uniqueness, grandiose fantasies, and charmingness. Narcissistic admiration is linked to the optimistic pursuit of one's uniqueness and ideas about one's own grandiosity (Back et al., 2013). Narcissistic rivalry consists of striving for supremacy, devaluation of others, and aggressiveness. Narcissistic rivalry is associated with a motivation to reinstate and defend one's own superior status, especially when there is a comparison with perceived social rivals (Back et al., 2013). The resulting devaluing thoughts about others lead to hostile and socially insensitive behaviour that causes negative social outcomes (e.g., rejection and criticism).

The two-dimensional model of the NARC has been validated in a set of seven studies. The two facets showed different patterns in the prediction of maintaining close relationships, aggressiveness, and agentic and communal behaviours (Back et al., 2013). The NARC has been applied successfully in several studies. For example, the two dimensions helped to understand the raise and decline of narcissists' popularity over time (Leckelt, Küfner, Nestler, \& Back, 2015). In addition, the two facets of narcissism differently predicted malicious and 
benign envy (Lange et al., 2016) and revenge and avoidance (Fatfouta, Gerlach, SchröderAbé, \& Merkl, 2015). Recently, the two-factor structure of the NARC has been supported in a large representative sample with more than 4,000 participants and a large convenience sample with almost 12,000 participants (Leckelt et al., 2017).

\section{Narcissistic admiration and empowerment}

We propose that the two facets of narcissism differently predict employee empowerment, which is defined as "increased intrinsic task motivation manifested in a set of four cognitions reflecting an individual's orientation to his or her work role: meaning, competence, self-determination, and impact" (Spreitzer, 1995, p. 1443). We argue that narcissistic admiration and rivalry affect intrinsic motivation, which is a fundamental aspect of SDT, via their distinct underlying self-regulatory processes - self-enhancement and selfprotection. In particular, we expect employee narcissistic admiration to have a positive effect on empowerment. Self-regulatory enhancement efforts that form the basis of narcissistic admiration promote self-assured and dominant behaviours. These behaviours result in desired outcomes such as success, admiration, social status and praise that in turn boost the ego of the narcissist and reinforce the narcissist's actual grandiose self (Back et al., 2013).

Consequently, the narcissist's subjective monitoring of the correspondence between the desired grandiose and actually perceived self should result in a perceived regulatory fit (Back et al., 2013). This fit should be accompanied by positive emotions (Back et al., 2013), such as pride (Tracy \& Robins, 2004), that have a direct impact on employees' empowerment (Hu, \& Kaplan, 2015). Moreover, these social outcomes can be considered as performance feedback and rewards. Rewards have a positive relationship with empowerment because they recognise and reinforce personal competencies (Spreitzer, 1995). We therefore suggest that self-assured behaviour which is appreciated by the environment increases intrinsic motivation. Besides this, the narcissist's positive self-perceptions foster the cognitions describing empowerment, 
especially competence and impact. Furthermore, the self-enhancement aspect of narcissistic admiration corresponds to a desire for success (Baumeister, Tice \& Hutton, 1989). We believe that this desire for success as well as the narcissist's pursuit of one's uniqueness (Back et al., 2013) should positively influence the narcissist's motivation and sense of having choice and regulating actions (Deci, Connell, \& Ryan, 1989). We suggest that these strengthen the self-determination facet of empowerment. Based on our reasoning we hypothesise:

Hypothesis 1: Narcissistic admiration positively relates to empowerment.

\section{Narcissistic rivalry and empowerment}

In contrast, we expect employee narcissistic rivalry to have a negative influence on empowerment. If self-regulatory protection processes are activated, the narcissist's subjective monitoring of the correspondence between the desired grandiose self and the actually perceived self should result in a perceived regulatory misfit (Back et al., 2013). This misfit should be accompanied by negative emotions (Back et al., 2013) such as shame (Tracy \& Robins, 2004) that we expect to decrease intrinsic motivation and therefore empowerment. This is in line with Bandura (1991) who argues that self-regulatory processes "produce emotional effects that can undermine performance motivation" (p. 273). Besides this, the activation of self-protection efforts leads to a perceived ego threat (Back et al., 2013). Ego threat is conceptualised as a real or perceived challenge to an individual's self-esteem (Kinderman, Prince, Waller, \& Peters, 2003; McManus, Waller, \& Chadwick, 1996; Meyer, Waller, \& Watson, 2000). As self-esteem is positively related to empowerment (Spreitzer, 1995) - especially competence and impact - a threatened self-esteem caused by narcissistic rivalry should weaken these two empowerment components. Moreover, ego threat undermines a person's sense of personal control (Leary, Terry, Allen, \& Tate, 2009). This reduced sense of personal control should have a detrimental effect on empowerment which 
"reflects a personal sense of control in the workplace" (Mishra \& Spreitzer, 1998, p. 577). More precisely, threats undermine autonomy (Deci \& Ryan, 2000), which is an important aspect of intrinsic motivation (Gagné \& Deci, 2005), and thus should negatively affect the self-determination core dimension of empowerment. Taken together we hypothesise:

Hypothesis 2. Narcissistic rivalry negatively relates to empowerment.

\section{Narcissistic admiration, narcissistic rivalry, empowerment and voice}

Defined as a form of performance that includes making constructive suggestions to change (Van Dyne \& LePine, 1998), voice is a behaviour intended to improve organizational functioning (Morrison, 2011), which is highly appreciated by leaders (Van Dyne \& LePine, 1998). Voice behaviour includes speaking up and encouraging others to get involved in issues affecting the work group (Van Dyne \& LePine, 1998). Voice as a form of contextual performance is not controllable by information systems (Piccoli et al., 2004). Consequently, it is very important that employees have the intrinsic motivation to show voice behaviour. We thus suggest that empowerment positively influences voice because employees have to be intrinsically motivated to speak up.

Voice is a self-determined behaviour that is performed volitionally. For instance, Wehmeyer (1996) argues that an act is self-determined if a person acts autonomously, the behaviour is self-regulated and the individual responds to an event in a "psychologically empowered" manner (p. 24). All of these aspects characterise voice behaviour. Moreover, Wehmeyer (1996) and other scholars highlight empowerment as a form of intrinsic motivation (Deci \& Ryan, 1985, p. 35; Gagné \& Deci, 2005) and link empowerment to voice behaviour.

Empowered employees believe that their work has meaning and impact, which strengthens their motivation to get involved in decision making and negotiating with their leader, two examples of voice behaviour. When employees perceive high impact, they feel 
that their action at work is connected to important organizational outcomes (Bandura, 1991; Heckhausen \& Schulz, 1995; Tangirala \& Ramanujam, 2008). Therefore, empowered employees believe that they can effectively solve problems through personal action (Fuller, Marier, \& Hester, 2006; Heckhausen \& Schulz, 1995; Parker, Wall, \& Jackson, 1997). As they feel intrinsic motivation and recognise opportunities for change, they are keen to participate in discussions. Consistent with our reasoning, empowerment had a positive influence on voice behaviour among employees in the hospitality industry (Raub \& Robert, 2013). Integrating these arguments with Hypotheses 1 and 2, we suggest:

Hypothesis 3. Empowerment mediates the positive relation between narcissistic admiration and voice.

Hypothesis 4. Empowerment mediates the negative relation between narcissistic rivalry and voice.

\section{Implicit Followership Theories and narcissism}

People naturally categorise other persons relying on their "naïve" theories and automatically process social information (Engle \& Lord, 1997) to relieve cognition (Sy, 2010). At work, leaders categorise employees based on their social role and are guided by their implicit theories of their followers. Sy (2010, p. 74) defined implicit followership theories (IFTs) as an "individual's personal assumptions about the traits and behaviours that characterise followers", and these can be positive or negative (Sy, 2010). If a leader has positive IFTs, he or she perceives employees in a positive manner and ascribes positive attributes to them such as being hardworking, excited and loyal (Sy, 2010). IFTs operate automatically and might influence leaders' and employees' cognitions, affect and behaviour (Bodenhausen \& Macrae, 1998; Macrae \& Bodenhausen, 2000). In support, studies showed that performance differences between employees might largely stem from leaders' 
perceptions of employees and subsequent social interaction with them (Goodwin, Wofford, \& Boyd, 2000; Wofford \& Goodwin, 1994).

Research has shown that the effects of narcissism on work outcomes can depend on moderating factors (Nevicka, De Hoogh, Van Vianen, Beersma, \& McIlwain, 2011; De Hoogh, Den Hartog, \& Nevicka, 2015). This is in line with Back et al. (2013) who note that both self-enhancement and self-protection processes related to narcissistic admiration and rivalry can be affected by situational cues. We focus on IFTs - one of the most powerful contextual factors influencing workplace processes (Engle \& Lord, 1997; Sy, 2010) - as a moderating variable. According to SDT, individuals have an intrinsic need for selfdetermination (Gagné \& Deci, 2005). Increasing the empowerment of employees is a useful way to satisfy the employees' self-determination need (Nassar, 2017). However, there are social-contextual factors that can support or hinder empowerment (Deci \& Ryan, 2002; Gagné \& Deci, 2005). We propose that leaders’ IFTs can affect the relationships between employee narcissism and empowerment. We argued that narcissistic rivalry has a negative and narcissistic admiration a positive effect on empowerment (Hypotheses 1 and 2). Building on these ideas, we expect that leaders' IFTs can work as a buffer in the rivalry-empowerment relationship and strengthen the admiration-empowerment association.

SDT suggests that the interpersonal context affects the extent to which an individual is autonomous. Therefore, autonomy-supportive contexts enhance intrinsic motivation (Black \& Deci, 2000). We believe that leaders can create such an autonomy-supportive context if they have positive IFTs. Autonomy support (Deci \& Ryan, 1985) means that a person with a position of authority, which is the leader in our case, acknowledges the feelings of another person (i.e., the employee), provides information, opportunities of choice and minimises the use of pressure. Leaders with positive IFTs think their employees are loyal, hardworking, and productive, positively shaping the pattern of the leader-follower interactions (Sy, 2010). As a 
result, they help empowering their employees and "afford them wide discretion in managing their work and time" (Sy, 2010; p. 79), thus giving them autonomy and many opportunities of choice regarding their work. By providing this autonomy and simultaneously reducing monitoring and pressure, intrinsic motivation will increase and positively influence the employee's empowerment. Linking these considerations to Hypotheses 1 and 2, we suggest two interaction effects: First, we expect that leaders with positive IFTs help employees high on narcissistic rivalry to reduce the activation of self-protection efforts that lead to reduced feelings of autonomy and control. Providing more opportunities and less pressure should counteract perceived ego threats of employees high on narcissistic rivalry. As a result, the negative effect of narcissistic rivalry on empowerment should be weakened because positive IFTs work as a buffer. Moreover, we believe that leaders with positive IFTs increase the intrinsic motivation and empowerment of employees high on narcissistic admiration even more. Their self-regulatory enhancement processes boost their ego and increase empowerment. These processes should be additionally fostered by the autonomy-supporting context created by a leader with positive IFTs. Reducing control and giving more choice will be perceived as highly motivating by employees high on narcissistic admiration and in turn increase empowerment. Therefore, we hypothesise that positive IFTs attenuate the negative effect of narcissistic rivalry on empowerment and strengthen the positive effect of narcissistic admiration on empowerment:

Hypothesis 5. Leaders' positive IFTs moderate the negative relationship between employee narcissistic rivalry and empowerment such that the relationship will be weaker for leaders with positive IFTs.

Hypothesis 6. Leaders' positive IFTs moderate the positive relationship between employee narcissistic admiration and empowerment such that the relationship will be stronger for leaders with positive IFTs. 
Hypothesis 4 suggests empowerment to mediate the relationship of narcissistic rivalry with voice. Moreover, Hypothesis 5 asserts that leaders' positive IFTs moderate the negative association between narcissistic rivalry and voice. Integrating $\mathrm{H} 4$ with $\mathrm{H} 5$, we propose the following moderated mediation hypothesis (Edwards \& Lambert, 2007):

Hypothesis 7. There is a conditional indirect effect of narcissistic rivalry on voice such that the mediated effect of narcissistic rivalry on voice through empowerment is conditional on leaders' positive IFTs. The indirect effect is weaker for leaders with positive IFTs.

According to Hypothesis 3, empowerment mediates the relationship of narcissistic admiration with voice. Furthermore, Hypothesis 6 suggests that leaders' positive IFTs moderate the positive association between narcissistic admiration and voice. Integrating $\mathrm{H} 3$ with H6 (see overall model in Figure 1), we propose the following moderated mediation hypothesis (Edwards \& Lambert, 2007):

Hypothesis 8 . There is a conditional indirect effect of narcissistic admiration on voice such that the mediated effect of narcissistic admiration on voice through empowerment is conditional on leaders' positive IFTs. The indirect effect is stronger for leaders with positive IFTs.

\section{Method}

\section{Participants and Procedure}

To test our hypotheses, we conducted a multi-wave field study using multisource data to minimise common method concerns. ${ }^{1}$ As part of their thesis requirement, twelve business students recruited online a diverse sample of German employees and leaders from a broad

\footnotetext{
${ }^{1}$ The current study was part of a greater data collection effort. The sample was also used in another
} unpublished study. However, the other study addresses a different research question and uses a different theoretical framework. In addition, there is no variable overlap in the two studies. 
range of organizations. Participation was voluntary and confidential. Moreover, neither leaders nor employees received information about the evaluations of the respective other. Students first contacted leaders and asked them if they would participate in a study about personality and leadership. Upon agreement, students sent invitation e-mails to the leaders including a short description of the study and the link to an online survey. After assessing their implicit followership theories, leaders were asked to select the employee whose surname is the second in the alphabetic order of all his/her employees. The purpose of this procedure was to encourage an unbiased choice of employees, unaffected by any possible desires of the leaders for favourable employees. Leaders then evaluated the voice behaviour of the chosen employee and reported their demographics. Subsequently, employees received an e-mail including a link to their first online questionnaire (assessing narcissistic admiration, narcissistic rivalry and servant leadership). Four days after finishing the first survey, employees received the link to their second online-questionnaire (assessing empowerment and psychological safety). We used generated identification codes to match leaders' and employees' questionnaires.

Of 554 leaders contacted, 358 completed leader surveys (completion rate 64.6\%). Of 386 invited employees ${ }^{2}, 365$ finished the first employee survey (completion rate $94.6 \%$ ). Of the 336 employees who participated in the second questionnaire, 321 completed the survey (completion rate 95.5\%). We matched 286 leader-employee dyads. Data of 18 leaders were removed because they reported their own email addresses instead of their employees' addresses or sent the invitation emails to their peers or friends. ${ }^{3}$ As a result, the final sample

\footnotetext{
${ }^{2}$ Some leaders indicated the employees e-mail but subsequently did not continue to finish their questionnaire. Therefore, more employees were invited than leaders completed their survey.

${ }^{3}$ We checked the leaders' email-addresses and the email-addresses of the employees that the leaders reported. When both email-addresses were the same, the leaders sent the employee questionnaire to themselves
} 
consisted of 268 leader-employee dyads. To ensure a high quality of our data, we also carried out several checks. For example, we examined the duration needed to complete the surveys and the time of day of the participation. We did not have to eliminate further participants. $26.5 \%$ of the leaders were female and the leaders' average age was 46.89 years $(S D=9.83)$. $55.6 \%$ of the employees were female and their average age was 37.28 years $(S D=10.70)$. The majority of the employees $(60.1 \%)$ had contact with their leader several times daily and $52.6 \%$ indicated that they know their leader well or very well. $68.6 \%$ of the leaders worked in the upper or middle management level and the majority of the leaders $(52.6 \%)$ had a university degree. The average length of the employee-leader relationship was 13.0 years. Most leaders and employees worked in the automotive industry $(16.0 \%)$, but they were also employed in industries such as commerce (7.8\%), electrical industry (6.3\%), engineering (6.0\%), civil service (5.2\%), and healthcare (4.5\%).

\section{Measures}

Narcissistic admiration and rivalry. Employees completed the German18-item Narcissistic Admiration and Rivalry Questionnaire (Back et al., 2013) to assess narcissistic admiration and narcissistic rivalry. We used a 6-point Likert scale (1: strongly disagree - 6: strongly agree; admiration: $\alpha=.86$; rivalry: $\alpha=.89$ ). Sample items were "I show others how special I am", "Being a very special person gives me a lot of strength”, "I deserve to be seen as a great personality" (admiration) and "I secretly take pleasure in the failure of my rivals", "Most people won't achieve anything", "I react annoyed if another person steals the show from me" (rivalry).

instead of sending it to their follower. In addition, in the employee questionnaire, we asked respondents to report their relationship with the person who sent them the invitation to the employee questionnaire, i.e. the leader. Some respondents indicated that the person was a peer or friend, but not their leader. 
To test the proposed two-factor structure of the Narcissistic Admiration and Rivalry Questionnaire (NARQ; Back et al., 2013), we followed the approach of Back et al. (2013). Using Mplus 7 (Muthén \& Muthén, 2015), we tested a model of two correlated second-order factors - admiration and rivalry -, which both consisted of three first-order factors representing the three subscales, respectively (grandiosity, striving for uniqueness and charmingness for admiration and devaluation of others, striving for supremacy and aggressiveness for rivalry). Each first-order factor had three items as indicators. The model fit was acceptable $\left(\chi^{2}(129, \mathrm{~N}=268)=319.36, \mathrm{p}<.001, \mathrm{CFI}=.92, \mathrm{RMSEA}=.07, \mathrm{SRMR}=\right.$ .06). However, we had to fix the residual variance of striving to uniqueness to zero, because it was negative. A likely reason for this may be that the ratio between sample size and estimated parameters was rather low due to our relatively small sample size. This model with two second-order factors representing narcissistic rivalry and admiration showed a better fit than the model where all first-order factors loaded onto one second-order factor representing narcissism $\left[\chi^{2}(130, N=268)=429.55, p<.001, \mathrm{CFI}=.87, \mathrm{RMSEA}=.09, \mathrm{SRMR}=.08\right]$ and a significant improvement in $\chi^{2}$ over this more parsimonious model $\left[\Delta \chi^{2}(1)=110.19\right]$.

Leaders' positive Implicit Followership Theories (IFTs). To measure leaders' positive IFTs we used six items of Sy's (2010) IFT scale representing the dimensions industry (hardworking, productive, goes above and beyond) and good citizen (loyal, reliable, team player). The English items were translated into German by the first author and back translated into English by an English native speaker. Leaders indicated on a ten-point scale how characteristic each item was for employees in their group $(\alpha=.83)$. As recommended, we let leaders think of the employees in their group and not of employees in general in order to get more robust results (Epitropaki, Sy, Martin, Tram-Quon, \& Topakas, 2013).

Empowerment. Employees indicated their psychological empowerment using the German version of Spreitzer's (1995) 12-item scale (Schermuly, Meyer, \& Dämmer, 2013). 
We used a 7-point Likert scale (1: strongly disagree - 7: strongly agree; $\alpha=.90)$. A sample item was "The work I do is very important to me".

Voice. Leaders evaluated employee voice behaviour on three items from Van Dyne and LePine's (1998) measure using a 7-point Likert scale (1: strongly disagree - 7: strongly agree; $\alpha=.82$ ). The English items were translated into German by the first author and back translated by an English native speaker. The items were: This particular employee ... (1) develops and makes recommendations concerning issues that affect this work group, (2) communicates his/her opinions about work issues to others in this group even if his/her opinion is different and others in the group disagree with him/her, and (3) speaks up in this group with ideas for new projects or changes in procedures.

Control variables. To rule out alternative explanations for our findings, we controlled for two theoretical meaningful variables: servant leadership and psychological safety. Servant leaders want their employees to "improve for their own good, and view the development of followers as an end, in and of itself, not merely a means to reach the leader's or organization's goals" (Ehrhart, 2004, p. 69). Previous research has shown that servant leadership positively influences employee empowerment and voice (see Eva, Robin, Sendjaya, van Dierendonck, \& Liden, 2018 for a review). Specifically, employee-centred variables such as employee voice efficacy, empowerment, and psychological safety mediated the positive effect of servant leadership on voice behaviour (Chugtai, 2016; De Sousa \& van Dierendonck, 2014; Duan, Kwan, \& Ling, 2014; Eva et al., 2018). Employees evaluated their leaders' servant leadership behaviour using the German 7-item global servant leadership measure (SL-7; Lacroix \& Pircher Verdorfer, 2014; Liden et al., 2015) on a 7-point Likert scale (1: strongly disagree -7 : strongly agree; $\alpha=.81)$.

Moreover, psychological safety - the belief that performing risky behaviours will not incur personal harm (Detert \& Burris, 2007; Edmondson, 1999) - has been found to be a key 
variable in predicting voice behaviour (Detert \& Burris, 2007; Liang, Farh, \& Farh, 2012; Morrison, 2011; Mowbray, Wilkinson, \& Tse, 2015). The underlying logic is that employees who are afraid of potential losses from speaking up are more likely to remain silent (Detert \& Burris, 2007). Employees assessed their psychological safety using the German 6-item version (Baer \& Frese, 2003) of Edmondson's (1999) scale on a 7-point Likert scale (1: strongly disagree -7 : strongly agree; $\alpha=.77)$. The items referred to the organisation in line with Baer and Frese (2003). Sample items were "It is safe to take a risk in this organisation" and "Members of this team are able to bring up problems and tough issues".

As recommended, we tested the hypotheses with and without the control variables (Becker et al., 2016). Because the pattern of findings remained essentially the same, we only report the results with control variables.

\section{Results}

\section{Preliminary analyses}

We conducted confirmatory factor analyses using Mplus 7 (Muthén \& Muthén, 2015) to evaluate the discriminant validity of our key study measures. To reduce the number of indicator variables, we used parcels for the constructs narcissistic admiration, narcissistic rivalry, empowerment, positive IFTs, servant leadership, and psychological safety. We used the domain-representative approach for the multidimensional constructs (Little, Cunningham, Shahar, \& Widaman, 2002; Williams \& O’Boyle, 2008) empowerment (3 parcels), the two dimensions of narcissism ( 3 parcels each), and positive IFTs ( 3 parcels). For the unidimensional constructs servant leadership ( 3 parcels) and psychological safety (3 parcels), we used the item-to-construct balance approach (Williams \& O’Boyle, 2008). For voice we used the three items as indicators.

Parcels have advantages such as a higher reliability and communality (Little et al., 2002; MacCallum, Widaman, Zhang, \& Hong, 1999). Moreover, fewer parameters are 
needed to define the constructs. This is especially useful when sample sizes are relatively small such as in our case. However, parcelling items also has disadvantages (see Marsh, Lüdtke, Nagengast, Morin, \& Von Davier, 2013 for an overview). When latent constructs are measured, it is unlikely that the assumed unidimensionality of the construct as well as pure indicators are present (Marsh et al., 2013). Therefore, parcels may camouflage cross-loadings of items that would be revealed by item-level analyses (Little et al., 2002; Marsh et al., 2013). Thus, studies that aim to develop new scales should avoid parcelling. Despite disadvantages of the item parcelling approach, we used parcels as they can reduce idiosyncratic item characteristics, technical problems in the estimation of the model parameters and model identification, and because our sample size was relatively small (Marsh et al., 2013). Moreover, when the aim of scholars is to understand the hypothesized relations among latent variables, a parcelling approach is recommended (Williams \& O’Boyle, 2008).

Our hypothesised model with seven factors demonstrated very good fit and all parcels and items had significant factor loadings as expected $\left[\chi^{2}(168, \mathrm{~N}=268)=256.93, p<.001\right.$, $\mathrm{CFI}=.97, \mathrm{RMSEA}=.04, \mathrm{SRMR}=.05]$. This seven-factor model showed a significant improvement in $\chi^{2}$ over more parsimonious models, in which we set two factors of the same source (leader or follower) to load onto one factor: narcissistic admiration and narcissistic rivalry $\left[\Delta \chi^{2}(6)=273.53, p<.001\right]$; empowerment and narcissistic rivalry $\left[\Delta \chi^{2}(6)=906.08, p\right.$ $<.001]$; empowerment and narcissistic admiration $\left[\Delta \chi^{2}(6)=902.09, p<.001\right]$; voice and positive IFTs $\left[\Delta \chi^{2}(6)=338.58, p<.001\right]$, narcissistic admiration and servant leadership $\left[\Delta \chi^{2}(6)=326.58, p<.001\right]$, narcissistic rivalry and servant leadership $\left[\Delta \chi^{2}(6)=278.07, p<\right.$ $.001]$, servant leadership and psychological safety $\left[\Delta \chi^{2}(6)=238.08, p<.001\right]$, narcissistic admiration and psychological safety $\left[\Delta \chi^{2}(6)=294.30, p<.001\right]$, narcissistic rivalry and psychological safety $\left[\Delta \chi^{2}(6)=279.64, p<.001\right]$, empowerment and psychological safety 
$\left[\Delta \chi^{2}(6)=184.66, p<.001\right]$, empowerment and servant leadership $\left[\Delta \chi^{2}(6)=279.06, p<\right.$ $.001] .^{4}$

\section{Latent structural equation model}

Table 1 shows the means, standard deviations, and correlations of the observed variables. We tested our hypothesised relations in a latent structural equation model with Mplus 7 (Muthén \& Muthén, 2015) using maximum-likelihood estimation. Our hypotheses included moderation as well as indirect effects. We applied bootstrapping with 5000 draws to determine the significance of the indirect effects (Cheung \& Lau, 2008; MacKinnon,

${ }^{4}$ We also ran separate CFAs for each of our latent constructs with the full number of items to test the construct validity (CFAs for narcissistic admiration and rivalry narcissism can be found in the measures section). The analyses showed acceptable to very good model fit, and all items had significant factor loadings on intended factors. For empowerment, in line with Spreitzer (1995), we tested a second-order factor with four correlated first-order factors representing the empowerment facets of meaning, competence, self-determination and impact with three items each $\left(\chi^{2}(50, \mathrm{~N}=268)=134.25, p<.001, \mathrm{CFI}=.96, \mathrm{RMSEA}=.08, \mathrm{SRMR}=.06\right)$. For positive IFTs, we modeled a second-order factor with two correlated first-order factors representing the two facets of positive IFTs, industry and good citizen. Both first-order factors were measured with three items each $\left(\chi^{2}(8, \mathrm{~N}=268)=13.92, p=.08, \mathrm{CFI}=0.99, \mathrm{RMSEA}=.05, \mathrm{SRMR}=.03\right)$. We modeled servant leadership with seven items loading on one factor, resulting in very good fit $\left(\chi^{2}(14, \mathrm{~N}=268)=10.25, p=.74, \mathrm{CFI}=1.00\right.$, RMSEA $=.00$, SRMR $=.02$ ). For voice, we used three items that loaded on one factor. This model was just identified and thus, the number of degrees of freedom was 0 . As model fit cannot be tested with zero degrees of freedom, we added servant leadership as another construct to our analyses, which led to excellent model fit $\left(\chi^{2}(34, \mathrm{~N}=268)=37.55, p=.31, \mathrm{CFI}=1.00, \mathrm{RMSEA}=.02, \mathrm{SRMR}=.04\right)$. For psychological safety, we used the six items loading on one factor $\left(\chi^{2}(8, \mathrm{~N}=268)=30.10, p<.001, \mathrm{CFI}=0.96, \mathrm{RMSEA}=.10, \mathrm{SRMR}=.05\right)$. However, we allowed for correlated errors between two items that had a similar wording and the highest intercorrelation among all psychological safety items $(\mathrm{r}=.66, p<.001)$. Such specifications of parameters are justified as they represent nonrandom measurement error which can be caused by method effects e.g., similar items (Brown \& Moore, 2012; Byrne, Shavelson, \& Muthén, 1989). 
Lockwood, Hoffman, West, \& Sheets, 2002). To test the moderation effects, we used Klein and Moosbruggers' (2000) latent moderated structural model approach. In line with Preacher, Rucker and Hayes (2007), we analysed the conditional indirect effects at high and low values of the moderator ( \pm one standard deviation).

In support of Hypotheses 1 and 2, narcissistic rivalry was negatively related to empowerment $(b=-0.19, p<.05$, Table 2, Model 1), whereas narcissistic admiration had a positive relationship $(b=0.29, p<.001$, Table 2 , Model 1$)$. Moreover, empowerment was positively related to voice $(b=0.22, p<.05$, Table 2 , Model 7$)$. To test the mediation hypotheses, we estimated the two indirect effects in one model (Table 2, Model 1 and 7), which demonstrated good fit $\left[\chi^{2}(171, N=268)=274.44, p<.001, \mathrm{CFI}=.97, \mathrm{RMSEA}=.05\right.$, SRMR $=.06]$. In line with Hypotheses 3 and 4, both the indirect effect of narcissistic admiration on voice through empowerment (indirect effect $=0.07, S E=.03$, bootstrapped $95 \%$ CI $[0.01,0.17])$, and the indirect effect of narcissistic rivalry on voice trough empowerment (indirect effect $=-0.04, S E=0.02$, bootstrapped 95\% CI $[-0.12,-0.01]$ ) were significant.

In support of Hypothesis 5 stating that leaders' positive IFTs moderate the negative relationship between narcissistic rivalry and empowerment, the interaction was significant $(b$ $=0.16, p<.01$, Table 2, Model 3). We found significant negative slopes for narcissistic rivalry at medium $(b=-0.19, p<.05)$ and low levels of positive IFTs $(-1 S D ; b=-0.35, p<$ $.001)$. At high levels of positive IFTs $(+1 S D)$, however, the relation between narcissistic rivalry and empowerment was non-significant $(b=-0.03, p=.75$; see Figure 2$)$. Moreover, adding the interaction significantly improved the model fit. The fit of the moderated mediation model with the interaction was significantly better than the fit of the mediation model that included positive IFTs as main effect without the interaction, $\Delta \chi^{2}(1)=5.07, p<$ .01 . 
Hypothesis 6 proposes that positive IFTs moderate the positive relationship between narcissistic admiration and empowerment. However, the interaction effect was not significant ( $b=0.05, p=.44$, Table 2, Model 4), and thus H6 was not supported. We also tested a model in which we included both interaction effects simultaneously (Table, 2, Model 5). Interestingly, the interaction effect of narcissistic admiration and leaders' positive IFTs on empowerment was significant and negative $(b=-0.20, p<.05)$. However, we do not interpret this regression coefficient, as it is an unstable finding that emerged only when including the two control variables and also the interaction between narcissistic rivalry and positive IFTs.

Hypothesis 7 stated that empowerment mediates the interaction effect of narcissistic rivalry and positive IFTs on voice. In support, we found a significant conditional indirect effect of narcissistic rivalry on voice through empowerment. We compared the conditional indirect effect of narcissistic rivalry on voice through empowerment for positive IFTs at one $S D$ above the mean (indirect effect $=-0.01, S E=0.02$, bootstrapped 95\% CI [-0.06, 0.03], Table 2, Model 3 and 7), at the mean (indirect effect $=-0.04, S E=0.03$, bootstrapped $95 \% \mathrm{CI}$ $[-0.12,-0.01]$ ) and at one $S D$ below the mean (indirect effect $=-0.08, S E=0.04$, bootstrapped $95 \%$ CI $[-0.18,-0.02]$. The conditional indirect effect of narcissistic rivalry on voice through empowerment was only significant for low and medium levels of positive IFTs. As the interaction hypothesis H6 was not supported, we did not test the related Hypothesis 8 suggesting that empowerment mediates the interaction effect of narcissistic admiration and positive IFTs on voice.

The pattern of our results and hypothesized effects (Hypotheses 1-8) remained essentially the same when analysed without control variables.

\section{Discussion}

We examined two facets of employee narcissism and how they relate to voice behaviour. We drew on self-determination theory and considered the different underlying 
motivational processes of narcissistic admiration and rivalry to show their distinct effects on empowerment and voice. We found narcissistic rivalry to be negatively and narcissistic admiration to be positively related to empowerment, which in turn affected employee voice. Moreover, the negative relationship between narcissistic rivalry and empowerment was weaker when leaders had positive IFTs. The positive association between narcissistic admiration and empowerment was not moderated by leaders' positive IFTs. Our results show that the two dimensions of narcissism differentially influence voice via empowerment, and that the detrimental effect of narcissistic rivalry can be buffered.

\section{Theoretical implications}

Our findings provide new insights to the literature of narcissism at work, which has mostly focused on managerial narcissism and did not examine underlying motivational processes so far. We considered different self-regulatory processes that precede behaviours of narcissistic admiration and rivalry. Moreover, we used a self-determination framework to link narcissism with empowerment and voice. The self-enhancement and self-protection processes that come along with narcissistic admiration and rivalry (Back et al., 2013; Wurst et al., 2017) differently predicted empowerment - reflecting intrinsic motivation (Thomas \& Velthouse, 1990) - and in turn voice, which is a self-determined behaviour.

By differentiating the two facets of narcissism, we showed that the relationship between employee narcissism and work outcomes is multidimensional and not just simply positive or negative as found by previous research (Penney \& Spector, 2002; Soyer et al., 1999). We demonstrated that narcissistic rivalry negatively and narcissistic admiration positively predicted empowerment and in turn voice behaviour, thereby supporting the idea that narcissism can have a bright and a dark side (Back et al., 2013; Campbell et al., 2011). These findings might help to resolve previous inconsistent results of employee narcissism with outcomes such as job performance and satisfaction (Jonason et al., 2015; Judge et al., 
2006; Mathieu, 2013; Soyer et al., 1999), which are possibly due to neglecting the multidimensionality of narcissism and underlying self-regulatory dynamics. The present results might also point to drawbacks of using models that view narcissism as one global construct. Therefore, by using global models and its narcissism measures such as the widely used Narcissistic Personality Inventory (NPI, Raskin \& Hall, 1979) researchers might not be able to identify distinct effects of different facets of narcissism. Beyond Back et al. 's NARC model (2013), there might be also other facet models such as the three-factor model of narcissism including the dimensions leadership/authority, grandiose exhibitionism and entitlement/exploitativeness by Ackerman et al. (2011) that could help to identify distinct effects.

By examining leaders' IFTs as a socio-contextual moderator, we extend Back et al. (2013)'s NARC model. We specify a contextual characteristic that influences the behavioural effects triggered by the self-regulatory protection processes linked to narcissistic rivalry. Doing so, we also addressed calls for investigating boundary conditions of narcissism (Campbell et al., 2011; Johns, 2006; Nevicka et al., 2011, O’Boyle et al., 2012). We found that positive IFTs attenuate the negative effects of narcissistic rivalry on empowerment. Leaders with positive IFTs possibly foster an autonomy-supportive context that diminishes the self-protection efforts of employees high on narcissistic rivalry, leading to a less negative effect on empowerment. Therefore, we call attention to implicit theories as a critical boundary condition affecting narcissistic rivalry's negative impact. Furthermore, this result points to the importance of considering leadership as a social process involving leaders and employees. Our results fit in and expand the literature emphasizing the bilateral relationship and interaction between leader and employees (Graen \& Uhl-Bien, 1995).

However, a leader's positive IFTs did not strengthen the positive relationship between narcissistic admiration and empowerment. It is possible that an employee high on narcissistic 
admiration is intrinsically motivated to such an extent that the influence of the leader's IFTs only plays a negligible role. Moreover, it is conceivable that a narcissist who is focused on striving for uniqueness and realising his grandiose fantasies does pay less attention to the context created by the leader so that its influence is insignificant. This is in line with research showing that narcissistic admiration is related to self-absorption (Back et al., 2013).

However, future research could test whether other supportive contexts created by leaders or co-workers may strengthen the positive effects of narcissistic admiration.

\section{Practical Implications}

Our research provides implications for personnel selection and development. Our results showed that narcissistic rivalry negatively influenced employee intrinsic motivation and voice. Therefore, organizations should not select employees who score high on this narcissistic facet. Though, employees high on narcissistic admiration showed increased empowerment that benefited their voice behaviour. Thus, selecting employees, which are

high on narcissistic admiration, does not seem to be critical. In addition, we also demonstrated that employees' narcissistic rivalry did not always lead to negative work outcomes because a moderating factor influenced this relationship. Leaders' positive IFTs attenuated harmful effects of narcissistic rivalry. They are likely to positively affect perceived autonomy, decrease perceived pressure, self-regulatory protection efforts and ego threat. For these reasons, when selecting employees, one should not consider employee characteristics in isolation. Instead, the characteristics of employees should be considered in light of the leader's characteristics. We recommend organizations to raise the awareness and importance of implicit theories to help their leaders realise their IFTs and to consciously consider potential behavioural consequences.

\section{Limitations and future research}


The present research also has some limitations. One concern arises from the time of measurement of voice behaviour. We suggested empowerment to predict employee voice behaviour. Nevertheless, leaders rated the employee's voice behaviour prior to assessing employees' empowerment (see also Venkataramani \&Tangirala, 2010), thus raising the question of reverse causality. It is also possible that there is a bidirectionality in this relationship; employees who engage in voice behaviour could become more intrinsically motivated and empowered. However, we argue that empowerment reflecting intrinsic motivation precedes the self-determined behaviour of employee voice. This is in line with past research showing that intrinsic motivation influences behaviour (Dysvik, \& Kuvaas, 2011; Kuvaas, \& Dysvik, 2009; Martens, Gulikers, \& Bastiaens, 2004; Van der Werff, Steg, \& Keizer, 2013). Previous studies also showed that empowerment influences voice behaviour (Kwak, 2012; Park, 2015). Nevertheless, future research should seek to replicate this relationship by examining the associations in the assumed chronological order. Moreover, experimental research is necessary to establish causal inferences.

We found that leaders' IFTs buffered the negative effect of narcissistic rivalry on empowerment. Nevertheless, we did not investigate the process of how IFTs affect employees. We argued that the IFTs create an autonomy-supportive context, reduce the activation of self-protection efforts that lead to a perceived ego threat and thereby increase intrinsic motivation. We recommend future research to examine these underlying processes and test our assumptions.

The study sample consisted of leaders and employees from diverse German organizations. Thereby, we tried to improve the study's generalizability. Although our diverse sample helped to increase the generalizability of our results, it was not possible to control for extraneous factors that might have confounded the study results. Moreover, because the current study utilised a sample of German leaders and employees, the extent to 
which cultural differences played a role in influencing the results is not clear. Therefore, future studies should investigate whether our findings are generalizable across cultural contexts.

We examined how narcissistic rivalry and narcissistic admiration relate to empowerment. Future research could also explore if the two narcissism facets differentially affect other work outcomes, and if narcissistic rivalry negatively and narcissistic admiration positively influences these outcomes. Empowerment is one of the most important motivational constructs (Spreitzer, 1995). However, it might be interesting to investigate other motivational processes such as approach and avoidance motivation and their effects on task and contextual performance. There may also be distinct effects caused by the two narcissism facets and their underlying motivational self-regulatory processes. Studying approach and avoidance motivation could especially be useful when examining helping behaviour or employee goal setting (see also Covington, 2000; Rudolph, Roesch, Greitemeyer, \& Weiner, 2004).

We investigated voice behaviour using the definition and the items from Van Dyne and LePine's (1998). However, there are different types of voice. Burris (2012), for example, defined two types of voice - supportive voice and challenging voice. Challenging voice is characterised by speaking up in order to modify the status quo. Instead, supportive voice means that speaking up is intended to stabilise existing practices and policies, and to defend threat to the status quo (Burris, 2012). We suggest that narcissistic admiration and rivalry could possibly predict these forms of voice behaviour differently. Narcissists high on admiration strive for uniqueness and they have grandiose fantasies. Therefore, we expect that narcissistic admiration could foster challenging voice behaviour that also includes this idea of change and advancement. However, narcissists high on rivalry want to defend their own status especially when there is a comparison with perceived social rivals (Back et al., 2013). 
Such self-regulatory protection processes might hinder a behaviour that is directed towards progress and change. Consequently, we would expect narcissistic rivalry to be negatively related to challenging voice behaviour. Back et al. (2013) found that narcissistic admiration is correlated with openness, whereas rivalry was associated with other characteristics than openness. This finding could support our thinking. However, future studies should test our considerations.

\section{Conclusion}

In our study, we investigated two facets of narcissism - narcissistic admiration and rivalry - under a motivational lens by integrating them in a self-determination framework. We showed that narcissism as a multidimensional construct can have positive and negative effects on empowerment and voice because of different self-regulatory processes. Moreover, the negative effects can be tempered by the leader's IFTs. Our examination of narcissistic rivalry and admiration furthers theory on employee narcissism. We hope that this research promotes future work on employee narcissism and self-regulatory considerations. 


\section{References}

Ackerman, R. A., Witt, E. A., Donnellan, M. B., Trzesniewski, K. H., Robins, R. W., \& Kashy, D. A. (2011). What does the narcissistic personality inventory really measure? Assessment, 18, 67-87. http://dx.doi.org/10.1177/1073191110382845

Aghaz, A., Atashgah, M. S. S., \& Zoghipour, M. (2014). Narcissism and counterproductive workplace behaviors among Iranian managers and nonmanagerial employees. Asian Journal of Business Ethics, 3, 155-169. http://dx.doi.org/10.1007/s13520-014-0039-2

American Psychiatric Association. (1994). Diagnostic and statistical manual of mental disorders (4th ed.). Washington, DC: American Psychiatric Press. http://dx.doi.org/10.1176/appi.books.9780890425596

Ames, D. R., Rose, P., \& Anderson, C. P. (2006). The NPI-16 as a short measure of narcissism. Journal of Research in Personality, 40, 440-450. http://dx.doi.org/10.1016/j.jrp.2005.03.002

Back, M. D., Küfner, A. C., Dufner, M., Gerlach, T. M., Rauthmann, J. F., \& Denissen, J. J. (2013). Narcissistic admiration and rivalry: Disentangling the bright and dark sides of narcissism. Journal of Personality and Social Psychology, 105, 1013-1037. http://dx.doi.org/10.1037/a0034431

Baer, M., \& Frese, M. (2003). Innovation is not enough: Climates for initiative and psychological safety, process innovations, and firm performance. Journal of Organizational Behavior, 24, 45-68. http://dx.doi.org/10.1002/job.179

Bandura, A. (1991). Social cognitive theory of self-regulation. Organizational Behavior and Human Decision Processes, 50, 248-287. http://dx.doi.org/10.1016/07495978(91)90022-L 
Baumeister, R. F., Tice, D. M., \& Hutton, D. G. (1989). Self-presentational motivations and personality differences in self-esteem. Journal of Personality, 57, 547-579. http://dx.doi.org/10.1111/j.1467-6494.1989.tb02384.x

Becker, T. E., Atinc, G., Breaugh, J. A., Carlson, K. D., Edwards, J. R., \& Spector, P. E. (2016). Statistical control in correlational studies: 10 essential recommendations for organizational researchers. Journal of Organizational Behavior, 37, 157-167. http://dx.doi.org/10.1002/job.2053

Black, A. E., \& Deci, E. L. (2000). The effects of instructors' autonomy support and students' autonomous motivation on learning organic chemistry: A self-determination theory perspective. Science Education, 84, 740-756. http://dx.doi.org/10.1002/1098237X(200011)84:6\%3C740::AID-SCE4\%3E3.0.CO;2-3

Bodenhausen, G. V., \& Macrae, C. N. (1998). Stereotype activation and inhibition. In R. S. Wyer Jr. (Ed.), Advances in Social Cognition (Vol. 11, pp. 1-52). Mahwah, NJ: Erlbaum.

Brown, T. A., \& Moore, M. T. (2012). Confirmatory factor analysis. In R. H. Hoyle (Ed.), Handbook of structural equation modeling (pp. 361-379). New York, NY: Guilford Press.

Burris, E. R. (2012). The risks and rewards of speaking up: Managerial responses to employee voice. Academy of Management Journal, 55, 851-875. http://dx.doi.org/10.5465/amj.2010.0562

Byrne, B. M., Shavelson, R. J., \& Muthén, B. (1989). Testing for the equivalence of factor covariance and mean structures: The issue of partial measurement invariance. Psychological Bulletin, 105, 456-466. http://dx.doi.org/10.1037/0033-2909.105.3.456 
Campbell, W. K., Hoffman, B. J., Campbell, S. M., \& Marchisio, G. (2011). Narcissism in organizational contexts. Human Resource Management Review, 21, 268-284. http://dx.doi.org/10.1016/j.hrmr.2010.10.007

Carpenter, C. J. (2012). Narcissism on Facebook: Self-promotional and anti-social behavior. Personality and Individual Differences, 52, 482-486. http://dx.doi.org/10.1016/j.paid.2011.11.011

Chatterjee, A., \& Hambrick, D. C. (2007). It's all about me: Narcissistic chief executive officers and their effects on company strategy and performance. Administrative Science Quarterly, 52, 351-386. http://dx.doi.org/10.2189/asqu.52.3.351

Cheung, G. W., \& Lau, R. S. (2008). Testing mediation and suppression effects of latent variables: Bootstrapping with structural equation models. Organizational Research Methods, 11, 296-325. http://dx.doi.org/10.1177/1094428107300343

Chughtai, A. A. (2016). Servant leadership and follower outcomes: Mediating effects of organizational identification and psychological safety. The Journal of Psychology, 150, 866-880. http://dx.doi.org/10.1080/00223980.2016.1170657

Conger, J. A., \& Kanungo, R. N. (1988). The empowerment process: Integrating theory and practice. Academy of Management Review, 13, 471-482. http://dx.doi.org/10.5465/amr.1988.4306983

Covington, M. V. (2000). Goal theory, motivation, and school achievement: An integrative review. Annual Review of Psychology, 51, 171-200. http://dx.doi.org/10.1146/annurev.psych.51.1.171

Deci, E. L., Connell, J. P., \& Ryan, R. M. (1989). Self-determination in a work organization. Journal of Applied Psychology, 74, 580-590. http://dx.doi.org/10.1037/0021$\underline{9010.74 .4 .580}$ 
Deci, E. L., \& Ryan, R. M. (1985). Intrinsic motivation and self-determination in human behavior. New York: Plenum. http://dx.doi.org/10.1007/978-1-4899-2271-7

Deci, E. L., \& Ryan, R. M. (2000). The "what" and "why" of goal pursuits: Human needs and the self-determination of behavior. Psychological Inquiry, 11, 227-268. http://dx.doi.org/10.1207/S15327965PLI1104_01

Deci, E. L., \& Ryan, R. M. (Eds.). (2002). Handbook of self-determination research. University Rochester Press.

De Hoogh, A. H., Den Hartog, D. N., \& Nevicka, B. (2015). Gender differences in the perceived effectiveness of narcissistic leaders. Applied Psychology, 64, 473-498. http://dx.doi.org/10.1111/apps.12015

De Sousa, J. C. M., \& van Dierendonck, D. (2014). Servant leadership and engagement in a merge process under high uncertainty. Journal of Organizational Change Management, 27, 877-899. https://doi.org/10.1108/JOCM-07-2013-0133

Detert, J. R., \& Burris, E. R. (2007). Leadership behavior and employee voice: Is the door really open? Academy of Management Journal, 50, 869-884. http://dx.doi.org/10.5465/amj.2007.26279183

Duan, J., Kwan, H. K., \& Ling, B. (2014). The role of voice efficacy in the formation of voice behaviour: A cross-level examination. Journal of Management \& Organization, 20, 526-543. http://dx.doi.org/10.1017/jmo.2014.40

Dysvik, A., \& Kuvaas, B. (2011). Intrinsic motivation as a moderator on the relationship between perceived job autonomy and work performance. European Journal of Work and Organizational Psychology, 20, 367-387. http://dx.doi.org/10.1080/13594321003590630

Edmondson, A. (1999). Psychological safety and learning behavior in work teams. Administrative Science Quarterly, 44, 350-383. http://dx.doi.org/10.2307/2666999 
Edwards, J. R., \& Lambert, L. S. (2007). Methods for integrating moderation and mediation: a general analytical framework using moderated path analysis. Psychological Methods, 12, 1-22. http://dx.doi.org/10.1037/1082-989X.12.1.1

Ehrhart, M. G. (2004). Leadership and procedural justice climate as antecedents of unit-level organizational citizenship behavior. Personnel Psychology, 57, 61-94. http://dx.doi.org/10.1111/j.1744-6570.2004.tb02484.x

Engle, E. M., \& Lord, R. G. (1997). Implicit theories, self-schemas, and leader-member exchange. Academy of Management Journal, 40, 988-1010. http://dx.doi.org/10.5465/256956

Epitropaki, O., Sy, T., Martin, R., Tram-Quon, S., \& Topakas, A. (2013). Implicit leadership and followership theories "in the wild": Taking stock of information-processing approaches to leadership and followership in organizational settings. The Leadership Quarterly, 24, 858-881. http://dx.doi.org/10.1016/j.leaqua.2013.10.005

Eva, N., Robin, M., Sendjaya, S., van Dierendonck, D., \& Liden, R. C. (2018). Servant leadership: A systematic review and call for future research. The Leadership Quarterly. http://dx.doi.org/10.1016/j.leaqua.2018.07.004

Fatfouta, R., Gerlach, T. M., Schröder-Abé, M., \& Merkl, A. (2015). Narcissism and lack of interpersonal forgiveness: The mediating role of state anger, state rumination, and state empathy. Personality and Individual Differences, 75, 36-40.

\section{http://dx.doi.org/10.1016/j.paid.2014.10.051}

Foster, J. D., \& Trimm IV, R. F. (2008). On being eager and uninhibited: Narcissism and approach-avoidance motivation. Personality and Social Psychology Bulletin, 34, 1004-1017. http://dx.doi.org/10.1177/0146167208316688

Fuller, J. B., Marler, L. E., \& Hester, K. (2006). Promoting felt responsibility for constructive change and proactive behavior: Exploring aspects of an elaborated model of work 
design. Journal of Organizational Behavior, 27, 1089-1120.

http://dx.doi.org/10.1002/job.425

Gagné, M., \& Deci, E. L. (2005). Self-determination theory and work motivation. Journal of Organizational Behavior, 26, 331-362. http://dx.doi.org/10.1002/job.322

Goodwin, V. L., Wofford, J. C., \& Boyd, N. G. (2000). A laboratory experiment testing the antecedents of leader cognitions. Journal of Organizational Behavior, 21, 769-788. http://dx.doi.org/10.1002/1099-1379(200011)21:7\%3C769::AIDJOB53\%3E3.0.CO;2-J

Graen, G. B., \& Uhl-Bien, M. (1995). Relationship-based approach to leadership: Development of leader-member exchange (LMX) theory of leadership over 25 years: Applying a multi-level multi-domain perspective. The Leadership Quarterly, 6, 219247. http://dx.doi.org/10.1016/1048-9843(95)90036-5

Grijalva, E., \& Harms, P. D. (2014). Narcissism: An integrative synthesis and dominance complementarity model. The Academy of Management Perspectives, 28, 108-127. http://dx.doi.org/10.5465/amp.2012.0048

Grijalva, E., Harms, P. D., Newman, D. A., Gaddis, B. H., \& Fraley, R. C. (2015). Narcissism and leadership: A meta-analytic review of linear and nonlinear relationships. Personnel Psychology, 68, 1-47. http://dx.doi.org/10.1111/peps.12072

Heckhausen, J., \& Schulz, R. (1995). A life-span theory of control. Psychological Review, 102, 284-304. http://dx.doi.org/10.1037/0033-295X.102.2.284

Hoffman, B. J., Strang, S. E., Kuhnert, K. W., Campbell, W. K., Kennedy, C. L., \& LoPilato, A. C. (2013). Leader narcissism and ethical context: Effects on ethical leadership and leader effectiveness. Journal of Leadership \& Organizational Studies, 20, 25-37. http://dx.doi.org/10.1177/1548051812465891 
Hu, X., \& Kaplan, S. (2015). Is “feeling good” good enough? Differentiating discrete positive emotions at work. Journal of Organizational Behavior, 36, 39-58.

http://dx.doi.org/10.1002/job.1941

Johns, G. (2006). The essential impact of context on organizational behavior. Academy of Management Review, 31, 386-408. http://dx.doi.org/10.5465/amr.2006.20208687

Jonason, P. K., Wee, S., \& Li, N. P. (2015). Competition, autonomy, and prestige: Mechanisms through which the Dark Triad predict job satisfaction. Personality and Individual Differences, 72, 112-116. http://dx.doi.org/10.1016/j.paid.2014.08.026

Judge, T. A., LePine, J. A., \& Rich, B. L. (2006). Loving yourself abundantly: Relationship of the narcissistic personality to self-and other perceptions of workplace deviance, leadership, and task and contextual performance. Journal of Applied Psychology, 91, 762-775. http://dx.doi.org/10.1037/0021-9010.91.4.762

Kernberg, O. F. (1975). Borderline conditions and pathological narcissism. New York: Jason Aronson.

Kinderman, P., Prince, S., Waller, G., \& Peters, E. (2003). Self-discrepancies, attentional bias and persecutory delusions. British Journal of Clinical Psychology, 42, 1-12. http://dx.doi.org/10.1348/014466503762841977

Klein, A., \& Moosbrugger, H. (2000). Maximum likelihood estimation of latent interaction effects with the LMS method. Psychometrika, 65, 457-474. http://dx.doi.org/10.1007/BF02296338

Kuvaas, B., \& Dysvik, A. (2009). Perceived investment in employee development, intrinsic motivation and work performance. Human Resource Management Journal, 19, 217236. http://dx.doi.org/10.1111/j.1748-8583.2009.00103.x 
Kwak, W. J. (2012). Charismatic leadership influence on empowered and less empowered followers' voice: A mediated moderation model. Journal of Leadership, Accountability and Ethics, 9, 56-70.

Lacroix, M. \& Pircher Verdorfer, A. (2014) Servant Leadership - Gütekriterien einer deutschen Adaption des multidimensionalen Instruments von Liden und Kollegen (2008) zur Messung dienender Führung (Servant Leadership: Psychometric properties of the German Version of Liden et al. 's (2008) multidimensional measure of servant leadership). Paper presented at the 49th Congress of the DGPs (Deutsche Gesellschaft für Psychologie), Bochum, Germany.

Lange, J., Crusius, J., \& Hagemeyer, B. (2016). The evil queen's dilemma: Linking narcissistic admiration and rivalry to benign and malicious envy. European Journal of Personality, 30, 168-188. http://dx.doi.org/10.1002/per.2047

Leary, M. R., Terry, M. L., Allen, A. B., \& Tate, E. B. (2009). The concept of ego threat in social and personality psychology: Is ego threat a viable scientific construct? Personality and Social Psychology Review, 13, 151-164. http://dx.doi.org/10.1177/1088868309342595

Leckelt, M., Küfner, A. C., Nestler, S., \& Back, M. D. (2015). Behavioral processes underlying the decline of narcissists' popularity over time. Journal of Personality and Social Psychology, 109, 856-871. http://dx.doi.org/10.1037/pspp0000057

Leckelt, M., Wetzel, E., Gerlach, T. M., Ackerman, R. A., Miller, J. D., Chopik, W. J., ... \& Richter, D. (2017). Validation of the Narcissistic Admiration and Rivalry Questionnaire short scale (NARQ-S) in convenience and representative samples. Psychological Assessment, 30, 86-96. http://dx.doi.org/10.1037/pas0000433 
Lee, K., \& Ashton, M. C. (2005). Psychopathy, Machiavellianism, and narcissism in the Five-Factor Model and the HEXACO model of personality structure. Personality and Individual Differences, 38, 1571-1582. http://dx.doi.org/10.1016/j.paid.2004.09.016

Liang, J., Farh, C. I., \& Farh, J. L. (2012). Psychological antecedents of promotive and prohibitive voice: A two-wave examination. Academy of Management Journal, 55, 71-92. http://dx.doi.org/10.5465/amj.2010.0176

Liden, R. C., Wayne, S. J., Meuser, J. D., Hu, J., Wu, J., \& Liao, C. (2015). Servant leadership: Validation of a short form of the SL-28. The Leadership Quarterly, 26, 254-269. http://dx.doi.org/10.1016/j.leaqua.2014.12.002

Liden, R. C., Wayne, S. J., \& Sparrowe, R. T. (2000). An examination of the mediating role of psychological empowerment on the relations between the job, interpersonal relationships, and work outcomes. Journal of Applied Psychology, 85, 407-416. http://dx.doi.org/10.1037/0021-9010.85.3.407

Little, T. D., Cunningham, W. A., Shahar, G., \& Widaman, K. F. (2002). To parcel or not to parcel: Exploring the question, weighing the merits. Structural Equation Modeling, 9, 151-173. http://dx.doi.org/10.1207/S15328007SEM0902_1

MacCallum, R. C., Widaman, K. F., Zhang, S., \& Hong, S. (1999). Sample size in factor analysis. Psychological Methods, 4, 84-99. http://dx.doi.org/10.1037/1082$\underline{989 X .4 .1 .84}$

Macrae, C. N., \& Bodenhausen, G. V. (2000). Social cognition: Thinking categorically about others. Annual Review of Psychology, 51, 93-120. http://dx.doi.org/10.1146/annurev.psych.51.1.93

Marsh, H. W., Lüdtke, O., Nagengast, B., Morin, A. J., \& Von Davier, M. (2013). Why item parcels are (almost) never appropriate: Two wrongs do not make a right- 
Camouflaging misspecification with item parcels in CFA models. Psychological Methods, 18, 257-284. http://dx.doi.org/10.1037/a0032773

Martens, R., Gulikers, J., \& Bastiaens, T. (2004). The impact of intrinsic motivation on elearning in authentic computer tasks. Journal of Computer Assisted Learning, 20, 368-376. http://dx.doi.org/10.1111/j.1365-2729.2004.00096.x

Mathieu, C. (2013). Personality and job satisfaction: The role of narcissism. Personality and Individual Differences, 55, 650-654. http://dx.doi.org/10.1016/j.paid.2013.05.012

MacKinnon, D. P., Lockwood, C. M., Hoffman, J. M., West, S. G., \& Sheets, V. (2002). A comparison of methods to test mediation and other intervening variable effects. Psychological Methods, 7, 83-104. http://dx.doi.org/10.1037/1082-989X.7.1.83

McManus, F., Waller, G., \& Chadwick, P. (1996). Biases in the processing of different forms of threat in bulimic and comparison women. The Journal of Nervous and Mental Disease, 184, 547-554. http://dx.doi.org/10.1097/00005053-199609000-00006

Meyer, C., Waller, G., \& Watson, D. (2000). Cognitive avoidance and bulimic psychopathology: The relevance of temporal factors in a nonclinical population. International Journal of Eating Disorders, 27, 405-410. http://dx.doi.org/10.1002/(SICI)1098-108X(200005)27:4\%3C405::AIDEAT4\%3E3.0.CO;2-H

Mishra, A. K., \& Spreitzer, G. M. (1998). Explaining how survivors respond to downsizing: The roles of trust, empowerment, justice, and work redesign. Academy of Management Review, 23, 567-588. http://dx.doi.org/10.5465/amr.1998.926627

Morf, C. C., Weir, C., \& Davidov, M. (2000). Narcissism and intrinsic motivation: The role of goal congruence. Journal of Experimental Social Psychology, 36, 424-438. http://dx.doi.org/10.1006/jesp.1999.1421 
Morrison, E. W. (2011). Employee voice behavior: Integration and directions for future research. The Academy of Management Annals, 5, 373-412. http://dx.doi.org/10.5465/19416520.2011.574506

Mowbray, P. K., Wilkinson, A., \& Tse, H. H. (2015). An integrative review of employee voice: Identifying a common conceptualization and research agenda. International Journal of Management Reviews, 17, 382-400. http://dx.doi.org/10.1111/ijmr.12045

Muthén, B., \& Asparouhov, T. (2015). Latent variable interactions. Retrieved from http://statmodel2.com/download/LVinteractions.pdf

Muthén, L. K., \& Muthén, B. O. (1998-2015). Mplus User's Guide. Seventh Edition. Los Angeles, CA: Muthén \& Muthén.

Nassar, M. A. (2017). Psychological empowerment and organisational change among hotel employees in Egypt. Research in Hospitality Management, 7, 91-98. http://dx.doi.org/10.1080/22243534.2017.1444716

Nevicka, B., De Hoogh, A. H., Van Vianen, A. E., Beersma, B., \& McIlwain, D. (2011). All I need is a stage to shine: Narcissists' leader emergence and performance. The Leadership Quarterly, 22, 910-925. http://dx.doi.org/10.1016/j.leaqua.2011.07.011

O'Boyle Jr, E. H., Forsyth, D. R., Banks, G. C., \& McDaniel, M. A. (2012). A meta-analysis of the dark triad and work behavior: A social exchange perspective. Journal of Applied Psychology, 97, 557-579. http://dx.doi.org/10.1037/a0025679

Park, C. K. (2015). Predicting Employee Engagement: An Exploration of the Roles of Transformational Leadership, Power Distance Orientation, Psychological Collectivism, and Psychological Empowerment in Korean Organizations. Retrieved from the University of Minnesota Digital Conservancy, http://hdl.handle.net/11299/177110 
Parker, S. K., Wall, T. D., \& Jackson, P. R. (1997). “That's not my job”: Developing flexible employee work orientations. Academy of Management Journal, 40, 899-929. http://dx.doi.org/10.5465/256952

Paulhus, D. L., \& Williams, K. M. (2002). The dark triad of personality: Narcissism, Machiavellianism, and psychopathy. Journal of Research in Personality, 36, 556-563. http://dx.doi.org/10.1016/S0092-6566(02)00505-6

Penney, L. M., \& Spector, P. E. (2002). Narcissism and counterproductive work behavior: Do bigger egos mean bigger problems?. International Journal of Selection and Assessment, 10, 126-134. http://dx.doi.org/10.1111/1468-2389.00199

Piccoli, G., Powell, A., \& Ives, B. (2004). Virtual teams: team control structure, work processes, and team effectiveness. Information Technology \& People, 17, 359-379. http://dx.doi.org/10.1108/09593840410570258

Pincus, A. L., \& Lukowitsky, M. R. (2010). Pathological narcissism and narcissistic personality disorder. Annual Review of Clinical Psychology, 6, 421-446. http://dx.doi.org/10.1146/annurev.clinpsy.121208.131215

Preacher, K. J., Rucker, D. D., \& Hayes, A. F. (2007). Addressing moderated mediation hypotheses: Theory, methods, and prescriptions. Multivariate Behavioral Research, 42, 185-227. http://dx.doi.org/10.1080/00273170701341316

Raskin, R., \& Hall, C. S. (1979). A Narcissistic Personality Inventory. Psychological Reports, 45, 590. http://dx.doi.org/10.2466/pr0.1979.45.2.590

Raub, S., \& Robert, C. (2013). Empowerment, organizational commitment, and voice behavior in the hospitality industry: Evidence from a multinational sample. Cornell Hospitality Quarterly, 54, 136-148. http://dx.doi.org/10.1177/1938965512457240 
Reina, C. S., Zhang, Z., \& Peterson, S. J. (2014). CEO grandiose narcissism and firm performance: The role of organizational identification. The Leadership Quarterly, 25, 958-971. http://dx.doi.org/10.1016/j.leaqua.2014.06.004

Ryan, R. M., \& Deci, E. L. (2000). Self-determination theory and the facilitation of intrinsic motivation, social development, and well-being. American Psychologist, 55, 68-78. http://dx.doi.org/10.1037/0003-066X.55.1.68

Rudolph, U., Roesch, S., Greitemeyer, T., \& Weiner, B. (2004). A meta-analytic review of help giving and aggression from an attributional perspective: Contributions to a general theory of motivation. Cognition and Emotion, 18, 815-848. http://dx.doi.org/10.1080/02699930341000248

Schermuly, C. C., Meyer, B., \& Dämmer, L. (2013). LMX and innovative behavior: The mediating role of psychological empowerment. Journal of Personnel Psychology, 12, 132-142. http://dx.doi.org/10.1027/1866-5888/a000093

Soyer, R. B., Rovenpor, J. L., \& Kopelman, R. E. (1999). Narcissism and achievement motivation as related to three facets of the sales role: Attraction, satisfaction and performance. Journal of Business and Psychology, 14, 285-304. https://doi.org/10.1023/A:1022147326001

Spreitzer, G. M. (1995). Psychological empowerment in the workplace: Dimensions, measurement, and validation. Academy of Management Journal, 38, 1442-1465. http://dx.doi.org/10.5465/256865

Sy, T. (2010). What do you think of followers? Examining the content, structure, and consequences of implicit followership theories. Organizational Behavior and Human Decision Processes, 113, 73-84. http://dx.doi.org/10.1016/j.obhdp.2010.06.001 
Tangirala, S., \& Ramanujam, R. (2008). Exploring nonlinearity in employee voice: The effects of personal control and organizational identification. Academy of Management Journal, 51, 1189-1203. http://dx.doi.org/10.5465/amj.2008.35732719

Thomas, K. W., \& Velthouse, B. A. (1990). Cognitive elements of empowerment: An "interpretive" model of intrinsic task motivation. Academy of Management Review, 15, 666-681. http://dx.doi.org/10.5465/amr.1990.4310926

Tracy, J. L., \& Robins, R. W. (2004). Putting the self into self-conscious emotions: A theoretical model. Psychological Inquiry, 15, 103-125. http://psycnet.apa.org/doi/10.1207/s15327965pli1502_01

Van der Werff, E., Steg, L., \& Keizer, K. (2013). It is a moral issue: The relationship between environmental self-identity, obligation-based intrinsic motivation and proenvironmental behaviour. Global Environmental Change, 23, 1258-1265. http://dx.doi.org/10.1016/j.gloenvcha.2013.07.018

Van Dyne, L., \& LePine, J. A. (1998). Helping and voice extra-role behaviors: Evidence of construct and predictive validity. Academy of Management Journal, 41, 108-119. http://dx.doi.org/10.5465/256902

Venkataramani, V., \& Tangirala, S. (2010). When and why do central employees speak up? An examination of mediating and moderating variables. Journal of Applied Psychology, 95, 582-591. http://dx.doi.org/10.1037/a0018315

Wehmeyer, M. L. (1996). Self-determination as an educational outcome: Why is it important to children, youth and adults with disabilities? In D. J. Sands \& M. L. Wehmeyer (Eds.), Self-determination across the life span: Independence and choice for people with disabilities (pp. 15-34). Baltimore: Paul H. Brookes. 
Weiser, E. B. (2015). \# Me: Narcissism and its facets as predictors of selfie-posting frequency. Personality and Individual Differences, 86, 477-481. http://dx.doi.org/10.1016/j.paid.2015.07.007

Williams, L. J., \& O'Boyle Jr, E. H. (2008). Measurement models for linking latent variables and indicators: A review of human resource management research using parcels. Human Resource Management Review, 18, 233-242. http://dx.doi.org/10.1016/j.hrmr.2008.07.002

Wisse, B., Barelds, D. P., \& Rietzschel, E. F. (2015). How innovative is your employee? The role of employee and supervisor Dark Triad personality traits in supervisor perceptions of employee innovative behavior. Personality and Individual Differences, 82, 158-162. http://dx.doi.org/10.1016/j.paid.2015.03.020

Wofford, J. C., \& Goodwin, V. L. (1994). A cognitive interpretation of transactional and transformational leadership theories. The Leadership Quarterly, 5, 161-186. http://dx.doi.org/10.1016/1048-9843(94)90026-4

Wurst, S. N., Gerlach, T. M., Dufner, M., Rauthmann, J. F., Grosz, M. P., Küfner, A. C., ... \& Back, M. D. (2017). Narcissism and romantic relationships: The differential impact of narcissistic admiration and rivalry. Journal of Personality and Social Psychology, 112, 280-306. http://dx.doi.org/10.1037/pspp0000113 
Table 1

Descriptive Statistics, Correlations, and Reliabilities

\begin{tabular}{|c|c|c|c|c|c|c|c|c|c|c|}
\hline & Variable & $M$ & $S D$ & 1 & 2 & 3 & 4 & 5 & 6 & 7 \\
\hline 1. & E. narcissistic rivalry & 2.19 & 0.86 & .89 & & & & & & \\
\hline 2. & E. narcissistic admiration & 3.11 & 0.84 & $.56 * *$ & .86 & & & & & \\
\hline 3. & E. empowerment & 5.77 & 0.75 & $-.15^{*}$ & $.15^{*}$ & .91 & & & & \\
\hline 4. & L. positive IFTs & 7.75 & 1.10 & .06 & $.15^{*}$ & $.16^{* *}$ & .83 & & & \\
\hline 5. & L. voice & 5.84 & 0.84 & -.03 & .06 & $.19 * *$ & $.26 * *$ & .83 & & \\
\hline 6. & E. servant leadership & 5.05 & 0.95 & $-.28 * *$ & -.02 & $.25 * *$ & .08 & .09 & .81 & \\
\hline 7. & E. psychological safety & 5.18 & 0.92 & $-.18 * *$ & .08 & $.43 * *$ & $.12 *$ & .03 & $.26 * *$ & .78 \\
\hline
\end{tabular}

Note. $N=268$ employees and their leaders. "E" indicates employees' ratings; "L" indicates leaders' ratings. IFTs $=$ Implicit Followership Theories. The numbers in bold on the diagonal are reliability coefficients.

$* * p<.01, * p<.05$ 
Table 2

Latent Multiple Regressions for Predicting Empowerment and Voice

\begin{tabular}{|c|c|c|c|c|c|c|c|c|c|c|c|c|c|c|}
\hline \multirow{2}{*}{$\frac{\text { Variable }}{\text { Control variables }}$} & \multicolumn{10}{|c|}{ Empowerment } & \multicolumn{4}{|c|}{ Voice } \\
\hline & \multicolumn{2}{|c|}{ Model 1} & \multicolumn{2}{|c|}{ Model 2} & \multicolumn{2}{|c|}{ Model 3} & \multicolumn{2}{|c|}{ Model 4} & \multicolumn{2}{|c|}{ Model 5} & \multicolumn{2}{|c|}{ Model 6} & \multicolumn{2}{|c|}{ Model 7} \\
\hline Servant leadership & $0.13^{*}$ & $(0.07)$ & 0.13 & $(0.07)$ & 0.12 & $(0.07)$ & 0.12 & $(0.07)$ & $0.14^{*}$ & $(0.07)$ & 0.13 & $(0.09)$ & 0.10 & $(0.09)$ \\
\hline Psychological safety & $0.27 * *$ & $(0.06)$ & $0.26^{* *}$ & $(0.06)$ & $0.27 * *$ & $(0.06)$ & $0.27 * *$ & $(0.06)$ & $0.26 * *$ & $(0.06)$ & -0.06 & $(0.07)$ & -0.15 & $(0.08)$ \\
\hline \multicolumn{15}{|l|}{ Predictors } \\
\hline Narc. Admiration & $0.29 * *$ & $(0.09)$ & $0.27 * *$ & $(0.09)$ & $0.26^{* *}$ & $(0.09)$ & $0.27 * *$ & $(0.09)$ & $0.26 * *$ & $(0.09)$ & 0.17 & $(0.11)$ & 0.11 & $(0.12)$ \\
\hline Narc. Rivalry & $-0.19 *$ & $(0.08)$ & $-0.18 *$ & $(0.08)$ & $-0.19 *$ & $(0.08)$ & $-0.19 *$ & $(0.08)$ & $-0.18^{*}$ & $(0.08)$ & -0.10 & $(0.10)$ & -0.06 & $(0.10)$ \\
\hline Pos. IFTs & & & 0.08 & $(0.04)$ & 0.07 & $(0.04)$ & 0.08 & $(0.04)$ & 0.07 & $(0.04)$ & & & & \\
\hline Narc. riv. x Pos. IFTs & & & & & $0.16^{* *}$ & $(0.05)$ & & & $0.27 * *$ & $(0.08)$ & & & & \\
\hline Narc. adm. x Pos. IFTs & & & & & & & 0.05 & $(0.06)$ & $-0.20 *$ & $(0.09)$ & & & & \\
\hline Empowerment & & & & & & & & & & & & & $0.22 *$ & $(0.09)$ \\
\hline$R^{2}$ & \multicolumn{2}{|c|}{$.24 * *$} & \multicolumn{2}{|c|}{$.26^{* *}$} & \multicolumn{2}{|c|}{$.28 * *$} & \multicolumn{2}{|c|}{$.26 * *$} & \multicolumn{2}{|c|}{$.37 * *$} & \multicolumn{2}{|c|}{0.03} & \multicolumn{2}{|c|}{0.07} \\
\hline
\end{tabular}

Note. $N=268$ employees and their leaders. Values are unstandardised regression estimates (standard error estimates are listed in parentheses). Narc. $=$ narcissistic. Adm. $=$ admiration. Riv. = rivalry. Pos. IFTs $=$ Leaders' positive Implicit Followership Theories. To compute $R^{2}$ of the Models 3 to 5 , 
we followed Muthén and Asparouhov (2015).

$* * p<.01, * p<.05$ 
Figure 1

Overall theoretical model

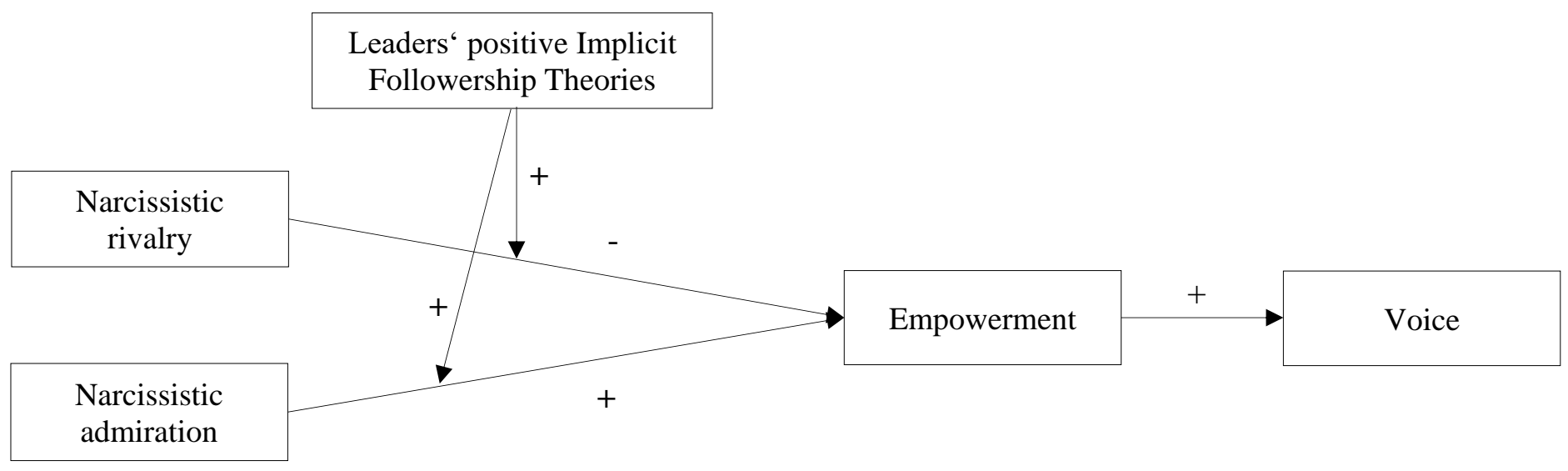


Figure 2

Empowerment Regressed on Narcissistic Rivalry and Moderated by Leaders' Positive Implicit Followership Theories (Table 2, Model 3)

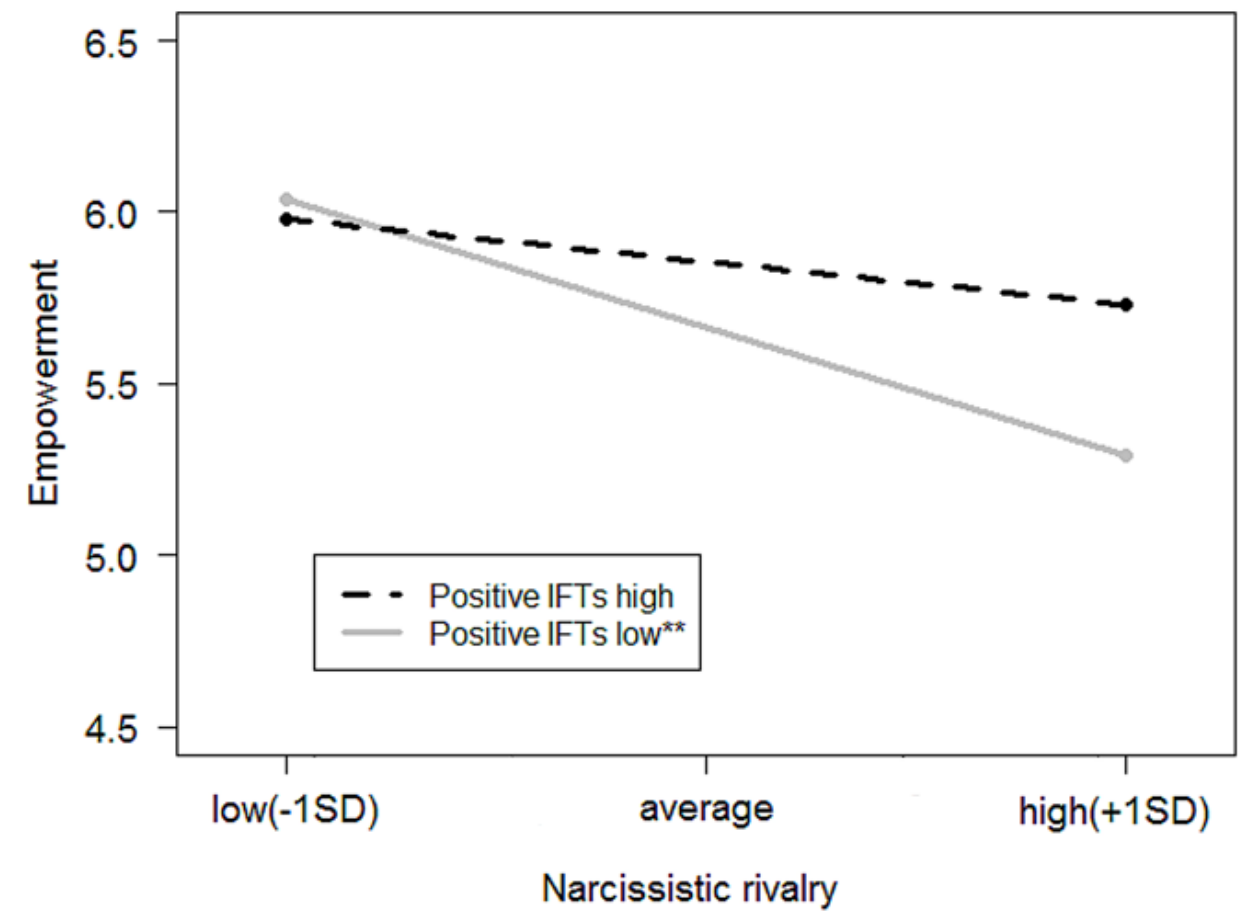

Note. $N=268, * * p<.01$. 
Figure 3

Results of the Latent Moderated Mediation Model.

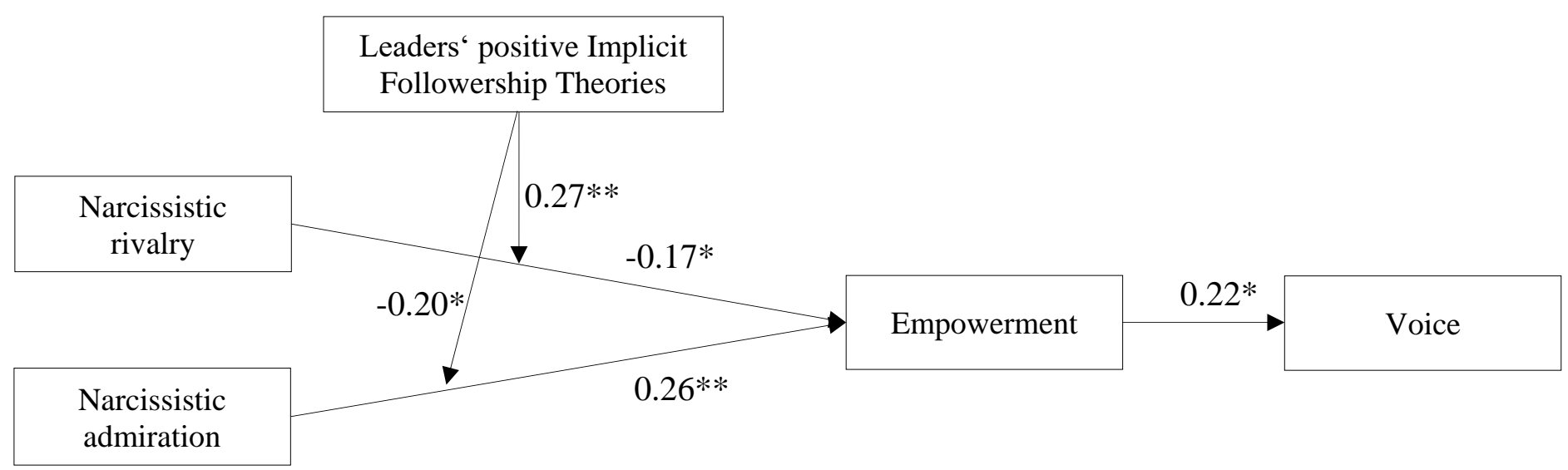

Note. All coefficients are unstandardised. The control variables are included in the analyses.

For ease of presentation, they are not depicted in the figure.

$N=268,{ }^{*} * p<.01, * p<.05$ 